\title{
Diagnostic Scoring System for Atrial Fibrillation in Ischemic Stroke
}

\author{
Erick Hoetama' ${ }^{1}$ Bambang Hermawan' , I Gusti Made Sunia ${ }^{2}$
}

I dr. H. Marsidi Judono Hospital, Tanjung Pandan, Provinsi Bangka Belitung

${ }^{2}$ dr. Ben Mboi Hospital, Ruteng, Provinsi Nusa Tenggara Timur
Background \& Objectives. Atrial Fibrillation (AF) is the most common arrhytmia that is found in daily practices. Patients with AF have four- to five-fold increased risk of developing ischemic stroke compared to normal population. Diagnosing AF can sometimes be quite difficult especially in the setting of paroxysmal AF. Moreover, paroxysmal AF can also increase the risk of thromboembolic complications. Some cases of cryptogenic stroke are believed to be cardioembolic in origin which caused by occult AF. This study aimed to develop a simple scoring system to detect patients with ischemic stroke most likely to have AF, so that recurrent stroke can be prevented.

Methods. We conducted diagnostic study using cross sectional design. Total I 73 subjects were gathered. Those subject were patients with ischemic stroke admitted in Belitung or Ruteng General Hospital from January 2014 until August 20I5. Data collected were subjects' characteristics, hypertension, diabetes, obesity, dyslipidemia, smoking history, congestive heart failure (CHF), alcohol consumption, valvular heart disease, chronic obstructive pulmonary disease, myocardial infarct history, previous stroke, Modified National Institutes of Health Stroke Scale (mNIHSS) score, and left atrial diameter (LAD). We analyzed those data using bivariate and logistic regression multivariate analysis.

Results. Multivariate analysis showed significant relationship between AF and some of the variables, which are hypertension, diabetes, obesity, CHF, left atrial enlargement, age and mNHISS score. We developed 7-point scoring system derived from those variables. A cutoff score of 3 or higher has sensitivity $97,1 \%$ and specificity $54,3 \%$. Also, this scoring system has Area Under the Curve (AUC) value of 88,9\% (IK95\% 83, I\% - 94,7\%).

Conclusion. This scoring system uses only clinical and echocardiographic profile that are easy to do, so it can be utilized as a simple diagnostic tool to identify ischemic stroke patient who is likely to have AF. Future studies are needed to determine another possibly related parameters.

(J Kardiol Indones. 2016;37:19-27)

Keywords. Atrial fibrillation, ischemic stroke, diagnosis, scoring system. 
Jurnal

Kardiologi Indonesia

J Kardiol Indones. 2016;37:19-27

ISSN $0126 / 3773$

\title{
Sistem Skoring Diagnosis Fibrilasi Atrium pada Kasus Stroke Iskemik
}

\author{
Erick Hoetama', Bambang Hermawan', I Gusti Made Sunia²
}

\begin{abstract}
Pendahuluan. Fibrilasi Atrium (FA) merupakan aritmia tersering yang ditemukan pada praktik sehari-hari. Penderita FA mempunyai risiko stroke empat sampai lima kali lipat lebih besar dibandingkan populasi normal. Diagnosis FA kadang menjadi masalah khusus terutama pada FA yang bersifat paroksismal, padahal pasien dengan FA paroksismal tetap memiliki risiko stroke. Beberapa kasus stroke kriptogenik seringkali memiliki etiologi kardioembolik yang disebabkan oleh FA yang tidak terdeteksi. Penelitian ini bertujuan untuk mencari suatu sistem skoring sederhana untuk mendeteksi kemungkinan adanya fibrilasi atrium pada kasus stroke iskemik, sehingga kejadian stroke berulang dapat dicegah.

Metode. Penelitian ini merupakan studi diagnostik dengan desain potong lintang terhadap 173 pasien stroke iskemik yang dirawat inap di Rumah Sakit Umum Daerah (RSUD) Belitung atau RSUD Ruteng dalam rentang waktu Januari 2014-Agustus 2015. Data yang dikumpulkan berupa karateristik subjek, hipertensi, diabetes, obesitas, dislipidemia, merokok, gagal jantung kongestif, hipertiroid, konsumsi alkohol, penyakit katup, penyakit paru obstruktif kronik, riwayat infark miokard, riwayat stroke berulang, skor Modified National Institutes of Health Stroke Scale (mNIHSS), dan ukuran diameter atrium kiri. Dari data tersebut dilakukan analisis bivariat dilanjutkan analisis mutivariat menggunakan regresi logistik.

Hasil. Analisis multivariat menunjukkan hubungan yang bermakna antara variabel hipertensi, diabetes, obesitas, gagal jantung kongestif, dilatasi atrium kiri, usia, dan skor mNHISS dengan fibrilasi atrium. Dari variabel tersebut dibuat suatu sistem skoring dengan maksimal skor 7. Skor 3 atau lebih sebagai titik potong memiliki sensitivitas $97,1 \%$ dan spesifisitas $54,3 \%$. Nilai Area Under the Curve (AUC) dari sistem skoring ini adalah 88,9\% (IK95\% 83,1\% - 94,7\%).

Simpulan. Sistem skoring pada penelitian ini menggunakan profil klinis dan ekokardiografi yang mudah untuk dikerjakan, sehingga, dapat digunakan sebagai alat diagnostik sederhana untuk menilai kemungkinan adanya FA pada pasien dengan stroke iskemik. Penelitian lebih lanjut tetap diperlukan untuk menilai parameter-parameter lain yang mungkin berhubungan dengan kejadian FA pada pasien stroke iskemik tersebut.
\end{abstract}

(J Kardiol Indones. 2016;37:19-27)

Kata Kunci. Fibrilasi atrium, stroke iskemik, diagnosis, sistem skoring.

\author{
Alamat Korespondensi \\ dr. Erick Hoetama, RSUD dr. H. Marsidi Judono, Tanjung Pandan, \\ Provinsi Bangka Belitung. E-mail: erick.hoetama@gmail.com
}

\section{Pendahuluan}

$\mathrm{F}$ ibrilasi atrium (FA) merupakan aritmia tersering yang ditemukan pada praktik sehari-hari. Prevalensi FA di kawasan Asia Pasifik pada tahun 2010 mencapai 340,2 dan 196 per 100000 populasi untuk laki-laki dan perempuan. Sedangkan 
di seluruh dunia, populasi penderita FA diketahui mencapai 20,9 juta laki-laki dan 12,6 juta perempuan. Angka tersebut diperkirakan akan terus meningkat per tahunnya. ${ }^{1}$ Satu hal yang membuat FA perlu mendapat perhatian khusus adalah risiko stroke kardioemboli yang ditimbulkannya. Stroke kardioemboli sendiri memiliki proporsi $17 \%-30 \%$ dari keseluruhan stroke iskemik, dan data menujukkan lebih dari 50\%-nya disebabkan oleh FA. ${ }^{2}$ Penderita FA memiliki risiko komplikasi tromboembolik 3-6 persen per tahunnya, lebih tinggi 4-5 kali lipat dibandingkan populasi normal. Risiko stroke pada pasien FA meningkat seiring dengan bertambahnya usia, yaitu $1,5 \%$ pada usia $50-59$ tahun hingga $25 \%$ pada usia diatas 80 tahun. $^{3}$

Pada kasus FA yang persisten atau permanen, diagnosis dapat dengan mudah ditegakkan baik dengan pemeriksaan fisik maupun penunjang seperti pemeriksan elektrokardigrafi (EKG). Meskipun demikian, pada kasus FA paroksismal seringkali diagnosis menjadi sulit untuk ditegakkan karena durasinya yang pendek, episodik dan seringkali tidak menimbulkan gejala. Pasien dengan FA paroksismal tetap memiliki risiko stroke, sehingga pencegahan sekunder dengan antitrombotik tetap perlu dilakukan. ${ }^{2}$ Sebagian kasus stroke ada yang diberi nama stroke kriptogenik, yaitu stroke yang penyebabnya seringkali tidak diketahui dengan pasti. Banyak studi yang mengatakan bahwa penyebab stroke kriptogenik salah satunya adalah kardioemboli akibat FA paroksismal. 2,4

Penting untuk diketahui juga bahwa FA merupakan faktor risiko independen terjadinya stroke berat dan kematian dalam 28 hari pasca kejadian stroke iskemik. ${ }^{5}$ Oleh karena itu, penelitian ini bertujuan untuk mencari suatu sistem skoring sederhana untuk mendeteksi kemungkinan adanya fibrilasi atrium pada kasus stroke iskemik, sehingga kejadian stroke berulang dapat dicegah.

\section{Metode}

Penelitian ini merupakan penelitian potong lintang (cross-sectional) skala kategorik berbasis uji hipotesis komparatif kelompok tidak berpasangan pada pasien stroke iskemik yang dirawat inap di Rumah Sakit Umum Daerah (RSUD) Belitung dan RSUD Ruteng selama periode Januari 2014-Agustus 2015. Kriteria inklusi pada penelitian ini adalah pasien yang memenuhi kriteria stroke iskemik berdasarkan skor Siriraj yang dirawat inap di RSUD Belitung atau RSUD Ruteng selama Januari 2014-Agustus 2015. Kriteria eksklusi pada penelitian ini adalah pasien atau keluarga pasien menolak untuk berpartisipasi.

Data yang mencakup karateristik subjek, hipertensi, diabetes, obesitas dislipidemia, merokok, gagal jantung kongestif, hipertiroid, konsumsi alkohol, penyakit katup, penyakit paru obstruktif kronik (PPOK), riwayat infark miokard, riwayat stroke berulang, skor Modified National Institutes of Health Stroke Scale (mNIHSS), dan ukuran diameter atrium kiri. Variabel gagal jantung kongestif diklasifikasikan menjadi 2, yaitu Heart Failure with Reduced Ejection Fraction (HFrEF) bila fraksi ejeksi $\leq 40 \%$ dan Heart Failure with Preseerved Ejection Fraction (HFpEF) $>40 \% .{ }^{6}$ Skor mNHISS diklasifikasi kan menjadi 2 , yaitu skor $\geq 15$ (stroke berat), dan $<15$ (stroke ringan-sedang). ${ }^{5}$ Pembesaran diameter atrium kiri diklasifikasikan menjadi mild (4,1-4,6 cm pada lakilaki atau 3,9-4,2 cm pada perempuan), moderate (4,7$5,1 \mathrm{~cm}$ pada laki-laki atau $4,3-4,6 \mathrm{~cm}$ pada perempuan) dan severe $(\geq 5.2 \mathrm{~cm}$ pada laki-laki atau $\geq 4.7 \mathrm{~cm}$ pada perempuan). ${ }^{7}$ Kriteria obesitas yang digunakan pada penelitian adalah kriteria WHO untuk populasi Asia, yaitu apabila indeks massa tubuh $\geq 25 \mathrm{~kg} / \mathrm{m}^{2} .8$

Data yang terkumpul kemudian dicatat dalam lembar data, lalu dilakukan penyuntingan untuk menilai kelengkapan data. Pengolahan data menggunakan perangkat SPSS versi 22.0. Perhitungan nilai rata-rata hitung dan sebaran baku dilakukan untuk data yang bersifat kuantitatif apabila sebaran data normal. Jika sebaran data tidak normal, maka digunakan nilai median dan retang. Sedangkan untuk data kategorik dicantumkan frekuensi dan presentasenya.

Untuk uji statistik, pertama-tama variabel yang ada dianalisis secara bivariat menggunakan uji Chisquare atau uji Fisher jika tidak memenuji syarat. Batas kemaknaan yang digunakan adalah $\mathrm{p}<0,005$. Setelah itu, variabel yang mempunyai nilai $\mathrm{p}<0,25$ (atau nilai $p>0,25$ apabila dianggap bermakna oleh peneliti) dimasukkan dalam analisis multivariat. Analisis multivariat yang digunakan adalah regresi logisitk. Kemampuan prediksi skor yang didapatkan pada analisis multivariat untuk memperkirakan kemungkinan adanya FA dinilai dengan menggunakan kurva Receiver Operating Charateristic (AUC) dan menghitung nilai Area Under the Curve (AUC). Kemudian ditentukan titik potong skor dengan sensitivitas dan spesifisitas terbaik dalam memprediksi kemungkinan adanya FA. 


\section{Hasil}

Jumlah subjek penelitian selama periode Januari 2014-Agustus 2015 yang memenuhi kriteria inklusi sebanyak 173 orang (RSUD Ruteng 117 orang, RSUD Belitung 56 orang). Prevalensi FA pada penelitian ini ditemukan sebesar 20,2\%. Sebagian besar subjek mempunyai riwayat merokok $(58,4 \%)$ dan mengidap dislipidemia (52,6\%). Dari total $52,6 \%$ subjek yang diketahui menderita gagal jantung kongestif, 28,9\%-nya adalah gagal jantung dengan fraksi ejeksi yang menurun, sedangkan $23,7 \%$ sisanya adalah gagal jantung dengan fraksi ejeksi yang masih dalam batas normal. Rerata skor mNHISS pada penelitian ini adalah $14 \pm 6,9$, yang berarti sebagian besar subjek masuk dalam kriteria stroke ringansedang.

Pada analisis bivariat dinilai hubungan antara berbagai variabel dengan FA. Variabel yang memiliki nilai $\mathrm{p}<0,25$ nantinya akan dimasukkan dalam analisis multivariat. Variabel-variabel tersebut antara lain jenis kelamin, usia, hipertensi, diabetes, obesitas, dislipidemia, gagal jantung kongestif, hipertiroid, PPOK, skor mNHISS, dan pembesaran atrium kiri. Meskipun variabel penyakit katup memiliki nilai $p>0,25$, peneliti tetap memasukkannya pada analisis

Tabel 1. Karateristik subjek penelitian

\begin{tabular}{ll}
\hline Karateristik & Jumlah $(\%)$ \\
& $\mathrm{N}=153$ \\
\hline Perempuan & $107(61,8)$ \\
Rerata usia (tahun) & $66,5 \pm 6,1$ \\
$\quad$ Fibrilasi Atrium & $35(20,2)$ \\
Hipertensi & $69(39,9)$ \\
Diabetes & $75(43,4)$ \\
Dislipidemia & $91(52,6)$ \\
Merokok & $101(58,4)$ \\
Gagal jantung kongestif & \\
HFpEF & $43(24,9)$ \\
HFrEF & $46(26,6)$ \\
Hipertiroid & $12(6,9)$ \\
Konsumsi Alkohol & $8(4,6)$ \\
Penyakit Katup & $5(2,9)$ \\
PPOK & $31(17,9)$ \\
Riwayat MCI & $16(9,2)$ \\
Obesitas & $64(37,0)$ \\
Riwayat Stroke Berulang & $14(8,1)$ \\
Rerata Skor mNIHSS & $14 \pm 6,9$ \\
Rerata diameter atrium kiri (cm) & $4,2 \pm 0,4$ \\
\hline
\end{tabular}

multivariat karena menurut literatur penyakit katup memiliki hubungan kausal yang jelas dengan kejadian FA. Selain itu juga nilai p 0,266 tidak terlalu jauh dari batas nilai 0,25 .

Dari hasil analisis multivariat didapatkan variabel yang merupakan determinan diagnostik dari FA, yaitu hipetensi, diabetes, obesitas, gagal jantung kongestif, pembesaran atrium kiri, usia dan skor mNHISS. Untuk memudahkan dalam perhitungan probabilitas adanya FA pada pasien dengan stroke iskemik, maka dibuat suatu sistem skoring berdasarkan hasil analisis multivariat pada tabel 3. Sistem skoring terserbut dapat dilihat pada tabel 4 .

Dari hasil regresi logisitk sistem skoring pada tabel 5, dapat dibuat suatu persamaan untuk menilai probabilitas adanya FA pada pasien dengan stroke iskemik, yaitu :

$$
\begin{aligned}
& \mathrm{p}=1 /(1+\mathrm{e}-\mathrm{y}) \\
& \mathrm{y}=-6,345+(1,437 \mathrm{x} \text { total skor }) \\
& \text { dimana } \mathrm{p}=\text { probabilitas FA pada pasien dengan } \\
& \text { stroke iskemik. }
\end{aligned}
$$

Untuk menilai kualitas persamaan diatas, peneliti melakukan uji Hosmer dan Lameshow. Uji tersebut memberikan nilai p 0,675, sehingga dapat disimpulan bahwa persamaan diatas memiliki nilai kalibrasi yang baik. $(p>0,05)$. Untuk menilai validitas internal persamaan sistem skoring tersebut, peneliti menggunakan metode bootstrapping dengan jumlah sampel 1000. Hasilnya didapatkan nilai p 0,001, sehingga dapat dikatakan bahwa sistem skoring ini dapat digunakan pada populasi dengan karateristik yang sama dengan subjek penelitian namun dengan jumlah yang lebih besar. Selanjutnya peneliti melakukan analisis kurva ROC untuk mendapat nilai AUC dari sistem skoring tersebut. Selain itu dicari juga titik potong jumlah skor yang memiliki angka sensitivitas dan spesifisitas terbaik.

Nilai AUC yang didapat dari kurva ROC pada gambar 1 sebesar 88,9\% (IK95\% 83,1\% - 94,7\%). Hasil ini mengindikasikan bahwa sistem skoring yang dibuat memiliki nilai diskriminasi yang sangat memuaskan. Pada gambar 2, didapatkan titik potong kurva sensitvitas dan spesifisitas pada skor 3 . Berdasarkan hal tersebut, peneliti menetapkan nilai skor $\geq 3$ sebagai titik potong diagnsotik FA. Dengan demikian, skor $\geq 3$ dapat memperkirkan bahwa pasien stroke iskemik menderita FA dengan sensitivitas 97,1\% dan spesifisitas $54,3 \%$. 
Tabel 2. Hasil analisis bivariat

\begin{tabular}{|c|c|c|c|c|c|}
\hline \multirow[t]{2}{*}{ Variabel } & & \multicolumn{2}{|c|}{ Fibrilasi Atrium } & \multirow{2}{*}{$\begin{array}{c}\text { OR } \\
\text { IK95\% }\end{array}$} & \multirow[t]{2}{*}{$\mathrm{p}$} \\
\hline & & $\mathrm{Ya}$ & Tidak & & \\
\hline \multirow[t]{2}{*}{ Jenis Kelamin } & Laki-laki & $21(31,8)$ & $45(52,6)$ & 3,100 & 0,003 \\
\hline & Perempuan & $14(21,6)$ & $93(85,4)$ & $(1,444-6,656)$ & \\
\hline \multirow[t]{2}{*}{ Usia } & $\geq 65$ tahun & $19(33,9)$ & $37(66,1)$ & 3,252 & 0,002 \\
\hline & $<65$ tahun & $16(13,7)$ & $101(86,3)$ & $(1,509-6,961)$ & \\
\hline \multirow[t]{2}{*}{ Hipertensi } & Ya & $22(31,9)$ & $47(68,1)$ & 3,277 & 0,002 \\
\hline & Tidak & $13(12,5)$ & $91(87,5)$ & $(1,516-7,082)$ & \\
\hline \multirow[t]{2}{*}{ Diabetes } & Ya & $24(32,0)$ & $51(68,0)$ & 3,722 & 0,001 \\
\hline & Tidak & $11(11,2)$ & $87(88,8)$ & $(1,684-8,225)$ & \\
\hline \multirow[t]{2}{*}{ Dislipidemia } & Ya & $15(16,5)$ & $76(83,5)$ & 0,612 & 0,196 \\
\hline & Tidak & $20(24,4)$ & $62(75,6)$ & $(0,289-1,294)$ & \\
\hline \multirow[t]{2}{*}{ Merokok } & $\mathrm{Ya}$ & $22(21,8)$ & $79(78,2)$ & 1,264 & 0,548 \\
\hline & Tidak & $13(18,1)$ & $59(81,9)$ & $(0,589-2,714)$ & \\
\hline \multirow[t]{2}{*}{ Hipertiroid } & $\mathrm{Ya}$ & $5(41,7)$ & $7(58,3)$ & 3,119 & 0,068 \\
\hline & Tidak & $30(18,6)$ & $131(81.4)$ & $(0,926-10,504)$ & \\
\hline \multirow[t]{2}{*}{ Konsumsi Alkohol } & Ya & $2(25,0)$ & $6(75,0)$ & 1,333 & 0,664 \\
\hline & Tidak & $33(20,0)$ & $132(80,0)$ & $(0,257-6,909)$ & \\
\hline \multirow[t]{2}{*}{ Penyakit Katup } & Ya & $2(40,0)$ & $3(60,0)$ & 2,727 & 0,266 \\
\hline & Tidak & $33(19,6)$ & $135(80,4)$ & $(0,438-16,968)$ & \\
\hline \multirow[t]{2}{*}{ PPOK } & Ya & $9(29,0)$ & $22(71,0)$ & 1,825 & 0,178 \\
\hline & Tidak & $26(18,3)$ & $116(81,7)$ & $(0,754-4,420)$ & \\
\hline \multirow[t]{2}{*}{ Riwayat MCI } & Ya & $5(31,3)$ & $11(68,6)$ & 1,924 & 0,323 \\
\hline & Tidak & $30(19,1)$ & $127(80,9)$ & $(0,622-5,954)$ & \\
\hline \multirow[t]{2}{*}{ Riwayat stroke berulang } & Ya & $4(28,6)$ & $10(71,4)$ & 1,652 & 0,486 \\
\hline & Tidak & $31(19,5)$ & $128(80,5)$ & $(0,486-5,617)$ & \\
\hline \multirow[t]{2}{*}{ Obesitas } & Ya & $21(32,8)$ & $43(67,2)$ & 3,314 & 0,002 \\
\hline & Tidak & $14(12,8)$ & $95(87,2)$ & $(1,540-7,130)$ & \\
\hline \multirow[t]{3}{*}{ Gagal Jantung Kongestif } & $\mathrm{HFrEF}$ & $19(41,3)$ & $27(58,7)$ & - & 0,000 \\
\hline & HfpEF & $9(20,9)$ & $34(79,1)$ & & \\
\hline & Tidak & $7(8,3)$ & $77(91,7)$ & & \\
\hline \multirow[t]{2}{*}{ Skor mNHISS } & $\geq 15$ & $20(36,4)$ & $35(53,6)$ & 3,924 & 0,000 \\
\hline & $<15$ & $15(12,7)$ & $103(87,3)$ & $(1,814-8,487)$ & \\
\hline \multirow[t]{4}{*}{ Dilatasi atrium kiri } & Mild & $15(30,6)$ & $34(69,4)$ & - & 0,000 \\
\hline & Moderate & $12(36,4)$ & $21(63,6)$ & & \\
\hline & Severe & $3(42,9)$ & $4(57,1)$ & & \\
\hline & Normal & $5(6,0)$ & $79(94,0)$ & & \\
\hline
\end{tabular}

\section{Diskusi}

\section{Karateristik subjek penelitian}

Sebagian besar subjek yang menderita stroke iskemik adalah perempuan $(61,8 \%)$ dengan rerata usia 66,6 (SD $\pm 6,1)$. Penelitian oleh Darius et al dan Peter et al mendapatkan hasil yang berbeda. Pada kedua penelitian tersebut, didapatkan prevalensi stroke pada laki-laki lebih tinggi dibandingkan perempuan. ${ }^{9}, 10$ Terdapat beberapa alasan kenapa wanita memiliki prevalensi stroke yang cenderung lebih rendah dibandingkan laki-laki, antara lain pengaruh genetik, hormonal, dan tekanan darah. Estrogen diketahui mempunyai efek positif pada sirkulasi serebral, terutama dalam mencegah proses aterosklerosis. Beberapa penelitian mendapatkan bahwa tekanan darah pada laki-laki lebih tinggi dibandingkan perempuan dengan usia yang sama. ${ }^{10}$

Insiden stroke meningkat seiring dengan bertambahnya usia, dengan angka insiden terbesar didapatkan 
Tabel 3. Hasil analisis multivariat

\begin{tabular}{lcccccc}
\hline Variabel & B & S.E & Sig. & Exp(B) OR & \multicolumn{2}{c}{ 95\% C.I. for EXP B } \\
\cline { 6 - 7 } & & & & & Lower & Upper \\
\hline Hipertensi & 1,436 & 0,568 & 0,011 & 4,205 & 1,382 & 12,797 \\
Diabetes & 1,470 & 0,581 & 0,011 & 4,351 & 1,393 & 13,593 \\
Usia & 1,266 & 0,548 & 0,021 & 3,548 & 1,213 & 10,377 \\
Skor mNHISS & 1,467 & 0,548 & 0,007 & 4,338 & 1,482 & 12,698 \\
Obesitas & 1,186 & 0,570 & 0,037 & 3,275 & 1,072 & 10,007 \\
HFrEF & 2,001 & 0,698 & 0,004 & 7,399 & 1,884 & 29,057 \\
HFpEF & 1,496 & 0,750 & 0,046 & 4,465 & 1,027 & 19,405 \\
Dilatasi atrium kiri & & & & & & \\
Mild & 1,423 & 0,703 & 0,043 & 4,151 & 1,047 & 16,451 \\
Moderate & 1,600 & 0,716 & 0,025 & 4,955 & 1,218 & 20,146 \\
Severe & 2,537 & 1,238 & 0,040 & 12,648 & 1,117 & 20,269 \\
Konstanta & $-6,253$ & 1,022 & 0,000 & & & \\
\hline
\end{tabular}

Tabel 4. Sistem Skoring

\begin{tabular}{llcc}
\hline No & Variabel & Kategori & Skor \\
\hline 1 & Usia & $\geq 65$ & 1 \\
& & $<65$ & 0 \\
2 & Diabetes & Ya & 1 \\
& & Tidak & 0 \\
3 & Hipertensi & Ya & 1 \\
& & Tidak & 0 \\
4 & Obesitas & Ya & 1 \\
& & Tidak & 0 \\
5 & Skor mNIHSS & $\geq 15$ & 1 \\
& & $<15$ & 0 \\
6 & Gagal jantung kongestif & Ya & 1 \\
& & Tidak & 0 \\
7 & Dilatasi atrium kiri & Ya & 1 \\
& & Tidak & 0 \\
\hline
\end{tabular}

pada usia diatas 80 tahun. ${ }^{9}$ Pada penelitian didapatkan proposi subjek dengan stroke iskemik yang menderita FA sebesar 20,2\%. Angka ini tidak jauh dengan penelitianpenelitian lain yang mengatakan bahwa FA ditemukan pada $15-21 \%$ pasien yang mengalami stroke. ${ }^{5}$

\section{Hubungan usia dengan fibrilasi atrium}

Pada penelitian ini didapatkan jumlah subjek berusia $\geq 65$ tahun yang menderita FA sebanyak 19 orang $(33,9 \%)$, sedangkan jumlah subjek berusia $<65$ tahun yang menderita FA sebanyak 16 (13,7\%). Pada uji statistik diperoleh hubungan yang bermakna antara variabel usia dengan kejadian FA pada pasien stroke iskemik (OR 3,548; IK95\% 1,213-10,377; p 0,007). Penelitian oleh Bruce et al mengatakan bahwa risiko FA
Tabel 5. Analisis regresi logistik sistem skoring

\begin{tabular}{lccc}
\hline & B & S.E. & $p$ \\
\hline Total Skor & 1,437 & 0,245 & 0,000 \\
Konstanta & $-6,345$ & 0,951 & 0,000 \\
\hline
\end{tabular}

meningkat seiring dengan bertambahnya usia. Fibrilasi atrium jarang ditemukan pada individu dibawah usia 50 tahun. Sekitar 1 dari 200 individu berusia 50-59 tahun menderita FA, namun setelah diatas usia 80 tahun menjadi 1 dari 10 individu. Angka ini mulai

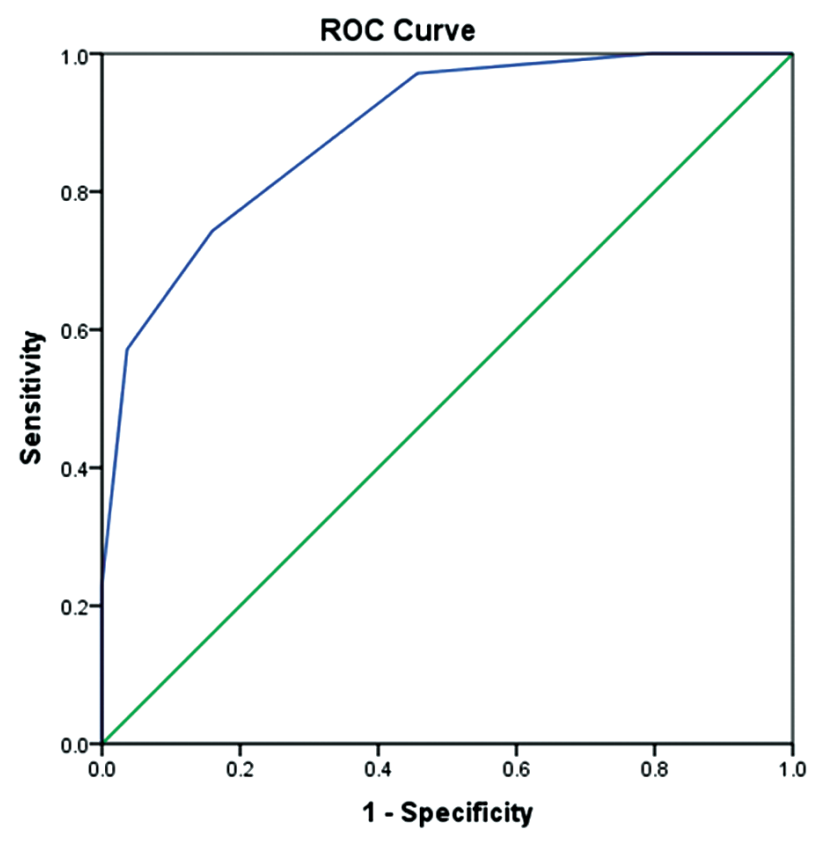

Diagonal segments are produced by ties.

Gambar 1. Kurva ROC sistem skoring 


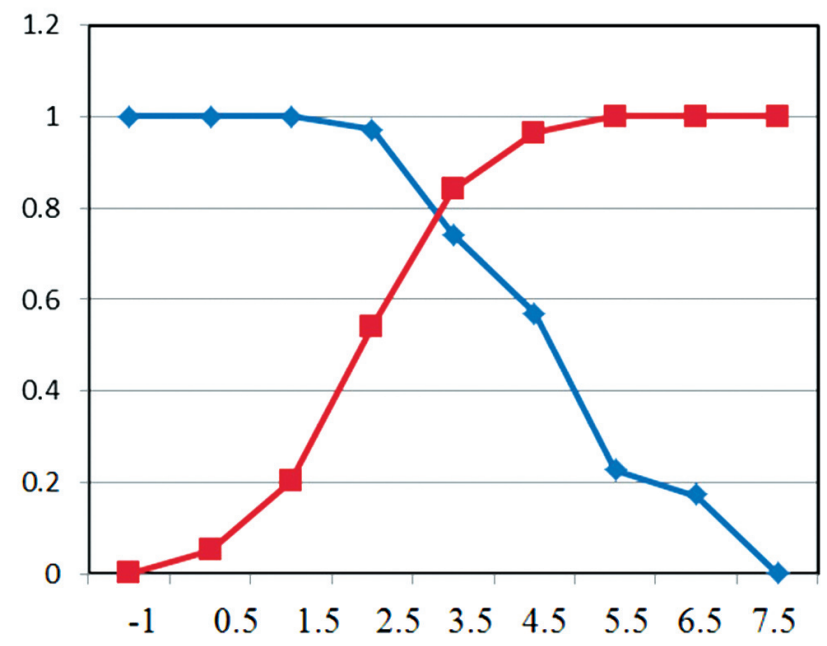

Gambar 2. Titik potong grafik sensitivitas dan spesifisitas sistem skoring

mengalami peningkatan signifikan setelah usia diatas 65 tahun. ${ }^{11}$

\section{Hubungan hipertensi dengan fibrilasi atrium}

Penelitian oleh Healey et al dan Lau et al mendapatkan bahwa hipertensi merupakan faktor risiko timbulnya FA. ${ }^{12,13}$ Hipertensi lama yang tidak diobati menyebabkan terjadinya hipertrofi ventrikel kiri, gangguan pengisian ventrikel dan pada akhirnya pembesaran atrium kiri akibat peningkatan tekanan pada atrium kiri. Selain itu, adanya aktivasi sistem renin angiotension aldosteron (RAAS) pada pasien hipertensi dapat menyebabkan terjadinya fibrosis dan gangguan konduksi di atrium. Hal-hal ini merupakan faktor predisposisi terjadinya FA. ${ }^{13} \mathrm{Hal}$ serupa didapatkan pada penelitian ini. Hasil analisis menunjukkan hubungan yang bermakna antara hipertensi dengan FA (OR 4,205; IK95\% 1,382-12,797; p 0,011).

\section{Hubungan diabetes dengan fibrilasi atrium}

Sebanyak $32 \%$ subjek dengan diabetes pada penelitian ini menderita FA, sedangkan pada pasien tanpa diabetes sebesar 11,2\%. Variabel diabetes mempunyai hubungan yang bermakna dengan kejadian FA (OR 4,351; IK95\% 1,393-13,593; p 0,005). Hubungan antara diabetes dengan FA belum sepenuhnya diketahui. Beberapa penelitian mendapatkan diabetes sebagai faktor risiko independen terjadinya FA, tetap sebagian lagi tidak menemukan hubungan yang bermakna. Gangguan metabolisme glukosa dan toleransi insulin dapat menyebabkan perubahan struktur miokardium baik di atrium maupun ventrikel. ${ }^{14}$ Selain itu, diabetes juga mempunyai hubungan erat dengan adanya peningkatan faktor-faktor inflamasi seperti $C$ reactive protein (CRP) yang turut berperan pada terjadinya FA. ${ }^{15}$ Penelitian oleh Tobias et al menemukan bahwa peningkatan risiko FA pada pasien diabetes sematamata hanya karena peningkatan angka kejadian faktor risiko lain seperti hipertensi dan obesitas. ${ }^{16}$

\section{Hubungan obesitas dengan fibrilasi atrium}

Pada penelitian ini didapatkan hubungan yang bermakna antara obesitas dengan kejadian FA. Proporsi subjek dengan obesitas yang menderita FA sebesar $32,8 \%$, sedangkan subjek tanpa obesitas sebesar $12,8 \%$. Frost et al pada penelitiannya mengungkapkan bahwa individu dengan obesitas mempunyai risiko 2,4 kali lipat untuk menderita FA. Angka tersebut meningkat seiring dengan meningkatnya BMI. ${ }^{17}$ Selain itu, Tsang et al juga mendapatkan bahwa obesitas meningkat risiko perubahan FA paroksimal menjadi FA yang permanen. ${ }^{18}$ Obesitas meningkatkan risiko terjadinya FA melalui berbagi jalur, antara lain efek metabolik, efek mekanik, peningkatan faktor inflamasi, peningkatan lemak perikardium, remodelling ventrikel, dan predisposisi penyakit jantung koroner. 19

Obesitas dan penyakit metabolik seperti hipertensi, dislipidemia dan resistensi insulin, saling berkaitan satu sama lain dalam meningkat risiko terjadinya FA. Salah satu efek mekanik dari obesitas salah adalah terjadinya obstructive sleep apneu (OSA). Pada pasien obesitas, prevalensi terjadinya OSA mencapai $90 \%$. OSA diketahui dapat meningkatkan aktivitas simpatik dan inflamasi vaskular. Selain itu OSA juga meningkatkan kemungkinan terjadinya hipertensi dan gangguan metabolik lain. Seluruh kondisi tersebut pada akhirnya menyebabkan mekanisme adaptasi struktural dan elektrofisiologi dari atrium. ${ }^{19}$

\section{Hubungan gagal jantung kongestif dengan fibrilasi atrium}

Proporsi subjek dengan $\mathrm{HFrEF}$ yang menderita FA sebesar 41,3\%, dan subjek dengan HFpEF sebesar 20,9\%. Baik HFrEF maupun HFpEF keduanya merupakan faktor risiko terjadinya FA dengan OR 
7,399 (IK95\% 1,884-29,057) dan 4,465 (IK95\% 1,027-19,405) berturut-turut. Hubungan antara FA dengan gagal jantung sangatlah kompleks. Gagal jantung dapat menyebabkan FA, begitu juga sebaliknya FA dapat menyebabkan gagal jantung. Keduanya menjadi siklus yang semakin memperburuk satu sama lain. ${ }^{20}$

Peningkatan denyut jantung baik saat istirahat maupu aktivitas serta hilangnya atrial kick menyebabkan penurunan curah jantung. Denyut jantung yang meningkat membuat waktu pengisian diastolik jantung menjadi berkurang, terlebih lagi ditambah dengan ketiadaan fungsi kontraktilitas atrium. Selain itu, FA diketahui dapat menyebakan tachycardiainduced cardiomyopathy melalui beberapa mekanisme, antara lain iskemia miokardium, habisnya cadangan energi miokardium, dan gangguan dalam regulasi ion kalsium. Sebaliknya, gagal jantung dapat menyebabkan FA akibat peningkatan tekanan pengisian diastolik, gangguan regulasi kalsium intraselular, dan aktivasi sistem neurohormonal yang terus menerus. ${ }^{20}$

\section{Hubungan skor mNHISS dengan fibrilasi atrium}

Pada penelitian ini didapatkan korelasi antara derajat berat ringannya stroke dengan FA. Proporsi subjek dengan stroke berat (skor mNHISS $\geq 15$ ) yang menderita FA sebesar 36,4\% dengan OR 4,338 (IK95\% 1,482-12,698). Penelitian oleh Kimura et al mendapatkan FA sebagai prediktor terjadinya stroke berat dan kematian dalam 28 hari pasca stroke. Pada penelitian tersebut dikatakan bahwa terdapat perbedaan patogenesis stroke akibat FA. Pertama, hampir sebagai besar stroke akibat FA merupakan kardioemboli, sehingga terjadi oklusi arteri serebral secara tiba-tiba tanpa adanya aliran darah kolateral. Kedua, pada pasien dengan FA terjadi penurunan aliran darah serebral dibandingkan pasien dengan irama sinus. Perbedaan ini menyebabkan stroke pada FA mempunyai prognosis yang lebih buruk sehubungan dengan area infark yang lebih luas, dan kerusakan neurologis yang lebih parah. ${ }^{5}$

\section{Hubungan diameter atrium kiri dengan fibrilasi atrium}

Penelitian ini mendapatkan dilatasi atrium kiri sebagai faktor risiko FA, dengan OR untuk masingmasing derajat dilatasi atrium kiri sebagai berikut: 4,151 (IK95\% 1,047-16,451) pada mild, 4,955
(IK95\% 1,218-20,146) pada moderate, dan 12,648 (IK95\% 1,117-20,269) pada severe. Dapat dilihat bahwa OR semakin meningkat seiring dengan derajat keparahan dilatasi atrium kiri. Penelitian oleh Anthony et al mendapatkan bahwa dilatasi atrium kiri meningkatkan risiko terjadinya FA. Adanya dilatasi atrium menyebabkan penipisan dan fibrosis dari serabut-serabut konduksi pada miokadium, sehingga tercipta kondisi yang dapat mencetuskan dan medukung proses terbentukan FA paroksismal maupun permanen. ${ }^{21}$

\section{Sistem skoring fibrilasi atrium pada pasien stroke iskemik}

Penelitian ini mendapatkan suatu sistem skoring dengan maksimal skor 7. Variabel yang termasuk didalamnya, antara lain hipertensi, diabetes, obesitas, gagal jantung kongestif, dilatasi atrium kiri, usia, dan skor mNHISS. Titik potong yang dipilih pada penelitan ini adalah skor $\geq 3$ dengan sensitivitas $97,1 \%$ dan spesifisitas $54,3 \%$. Nilai sensitivitas yang tinggi dinilai lebih penting oleh peneliti karena sistem skoring ini dibuat lebih untuk kepenting skrining.

Sampai saat ini terdapat beberapa sistem skoring FA pada kasus stroke iskemik. Yoshioka et al membuat sistem skoring yang diberi nama $\mathrm{PAB}$ score, yang terdiri dari 3 variabel yaitu penggunaan obat anti aritmia, dilatasi atrium kiri, dan skor Brain Natriuretic Peptide (BNP). ${ }^{22}$ Fuji et al menciptakan sistem skoring serupa dengan variabel National Institutes of Health Stroke Scale (NHISS), dilatasi atrium kiri, penyakit katup mitral dan kadar BNP. ${ }^{23}$ Penelitian lain oleh Marcelo et al mendapatkan sistem skoring dengan variabel usia, skor NHISS, dan dilatasi atrium kiri. ${ }^{24}$ Malik et al membuat sistem skoring lain dengan variabel dilatasi atrium kiri, usia, dan riwayat stroke. ${ }^{25}$ Dibandingkan dengan sistem skoring lain, sistem skoring pada penelitian ini menggunakan parameter yang lebih sederhana dan mudah untuk dikerjakan di fasilitas kesehatan dengan pemeriksaan penunjang yang terbatas. Selain itu, variabel yang dimasukkan dalam analisis penelitian ini lebih banyak, sehingga kemungkinan adanya peran faktor risiko lain dapat diketahui.

\section{Kesimpulan}

Sistem skoring untuk menilai kemungkinan adanya FA pada pasien stroke iskemik terdiri atas variabel 
hipertensi, diabetes, obesitas, gagal jantung kongestif, dilatasi atrium kiri, usia, dan skor mNHISS dengan fibrilasi atrium. Skor $\geq 3$ merupakan titik potong yang dipilih dengan sensitivitas $97,1 \%$ dan spesifisitas $54,3 \%$.

\section{Daftar Pustaka}

1. Chugh SS, Havmoller S, Narayanan K, Singh D, Rienstra M, Benjamin EJ, et al. Worldwide Epidemiology of Atrial Fibrillation: A Global Burden of Disease 2010 Study. Circulation. 2014;129:837-847.

2. Kisshore A, Vail A, Majid A, Dawson J, Lees KR, Tyrell PJ, et al. Detection of Atrial Fibrillation After Ischemic Stroke or Transient Ischemic Attack. Stroke.2014;45:520-526.

3. Saposnik G, Gladstone D, Raptis R, Zhou L, Hart GR. Atrial Fibrillation in Ischemic Stroke: Predicting Response to Thrombolysis and Clinical Outcomes. Stroke.2013;44:49-104.

4. Altieri M, Troisi P, Maesterini I, Lenzi GL. Cryptogenic Stroke: Cryptic Definition. Stroke. 2009;40:e530.

5. Kimura K, Minematsu K, Yamaguchi T. Atrial Fibrillation as a predictive factor for severe stroke and early death in 15831 patients with acute ischaemic stroke. J Neurol Neurosurg Psychiatry.2005;76:679-683.

6. Yancy CW, Jessup M, Bozkurt B, Butler J, Casey DE, Drazner $\mathrm{MH}$, et al. $2013 \mathrm{ACCF} / \mathrm{AHA}$ Guideline for the Management of Heart Failure: Executive Summary. Circulation. 2013;128:18101852.

7. Lang RM, Bierig M, Devereux RB, et al. Recommendations for chamber quantification: a report from the American Society of Echocardiography's Guidelines and Standards Committee and the Chamber Quantification Writing Group, developed in conjunction with the European Association of Echocardiography, a branch of the European Society of Cardiology. J Am Soc Echocardiogr.2005;18:1440-63.

8. Asia Pasific Cohort Studies Collaboration. Body mass index and cardiovascular disease in the Asia-Pacific Region: an overview of 33 cohorts involving 310000 participants. Int. J. Epidemiol. 2004;33(4):751-758.

9. Mozaffarian D, Benjamin EJ, Go AS, Arnett DK, Blaha MJ, Ferannti SD, et al. Heart Disease and Stroke Statistics-2015 Update. Circulation.2015;131(4):e29-e32.

10. Appelros P, Stegmayer B, Terent A. Sex differences in Stroke Epidemiology. Stroke.2009;40:1082-1090.

11. Psatys BM, Manolio TA, Kuller LH, Kronmal RA, Cuhsman M,
Fried LP, et al. Incidence of and Risk Factors of Atrial Fibrillation in Older Adults. Circulation. 1997;96:2455-2461.

12. Healey JS, Conolly SJ. Atrial fibrillation: hypertension as a causative agent, risk factor for complications, and potential therapeutic target. Am J Cardiol.2003;91(10A):9G-14G.

13. Lau YF, Hiu KH, Siu CW, Tse HF. Hypertension and atrial fibrillation: epidemiology, pathophysiology and therapeutic implications. Journal of Human Hypertension.2012;26:563-569.

14. Sun Y, Hu D. The link between diabetes and atrial fibrillation: cause or correlation. J Cardiovasc Dis Res.2010;1(1):10-11.

15. Bandemer S. Merkel S, Doffour AN, Weber MW. Diabetes and atrial fibrillation: stratification and prevention of stroke risks. EPMA Journal.2014;5:17

16. Schoen T, Pradhan AD, Albert CM, Conen D. Type 2 Diabetes Mellitus and Risk of Incident Atrial Fibrillation in Women. J Am Coll Cardiol.2012;60(15):1421-1428.

17. Frost L, Hune LJ, Vestergaard P. Overweight and obesity as risk factors for atrial fibrillation or flutter: the Danish Diet, Cancer, and Health Study. Am J Med. 2005;118:489-495.

18. Tsang TS, Barnes ME, Miyasaka Y, Cha SS, Bailey KR, Verzosa GC, Seward JB, Gersh BJ. Obesity as a risk factor for the progression of paroxysmal to permanent atrial fibrillation: a longitudinal cohort study of 21 years. Eur Heart J. 2008;29:2227-2233.

19. Magnani JW, Hylek EM, Apovian CM. Obesity Begets Atrial Fibrillation.Circulation. 2013;128:401-405.

20. Anter E, Jessup M, Callans DJ. Atrial Fibrillation and Heart Failure. Circulation.2009; 119: 2516-2525.

21. Sanfillipo AJ, Abascal VM, Sheehan M, Oertel LB, Harrigen P, Hughes RA. Atrial enlargement as a Consequence of Atrial Fibrillation. Circulation.1990;82:792-797.

22. Yoshioka K, Watanabe K, Zeniya S, Ito Y, Kanazawa T, Tomita M. A Score for Predicting Paroxysmal Atrial Fibrillation in Acute Stroke Patients: iPAB Score. J Stroke Cerebrovasc Dis. 2015; 15:344-345.

23. Fuji S, Shibazaki K, Kimura K, Aoki J. A simple score for predicting paroxysmal atrial fibrillation in acute ischemic stroke. J Neurol Sci. 2013;328(1-2):83-6.

24. Figueiredo MM, Rodrigues AC, Alves BM, Neto MC, Silva GS. Score for atrial fibrillation detection in acute stroke and transient ischemic attack patients in a Brazilian population: The acute stroke atrial fibrillation scoring system. Clinics (Sao Paulo). 2014;69(4): 241-246.

25. Malik S, Hicks WJ, Schultz J, Penstone P, Katramandos AM, Russman AN. Development of a scoring system for atrial fibrillation in acute stroke and transient ischemic attack patients: the LADS scoring system. J Neurol Sci.2011;301(1-2):27-30. 